\title{
Non communicable diseases persist despite being overshadowed by Covid-19 globally
}

\author{
James K Tumwine
}

Editor in Chief, African Health Sciences.

Email: kabaleimc@gmail.com

DOI: https://dx.doi.org/10.4314/ahs.v21i1.1

Cite as: Tumwine JK. Non communicable diseases persist despite being overshadowed by Covid-19 globally. i-iv. https:// dx.doi. org/10.4314/abs.v21i1.1

In this March 2021 issue, we start with interesting papers on non-communicable diseases.

Thus, Jian Ma and colleagues have a meta-analysis on the efficacy of dapagliflozin in type 1 diabetes mellitus. ${ }^{1}$ Keeping with the diabetes theme we have papers on vitamin $\mathrm{D}$ receptor gene in patients with type 2 diabetes mellitus, ${ }^{2}$ TCF7L2 gene polymorphism ${ }^{3}$, overweight ${ }^{4}$ and knowledge, attitude and practice in the Sudan ${ }^{5}$. Continuing with the NCD theme, we bring you papers on cancer of the breast ${ }^{6,7}$, childhood tumors ${ }^{8}$, oncology nursing care in Mexico ${ }^{9}$, and multiple myeloma in Uganda. ${ }^{10}$ We then have papers on hypertension ${ }^{11,12}$ cholesterol and aortic dilatation ${ }^{13}$, and heart rates in smoker and nonsmoker athletes. ${ }^{14}$ You talk of smoking! Gazibara and others write for us an interesting article on differences among former light and heavy smokers in a post conflict setting. ${ }^{15}$ Then comes the paper on risk factors for hazardous drinking among South African and Belgian University Students. ${ }^{16}$

Nyoni-Kachambwa's paper on skin bleaching ${ }^{17}$ in Zimbabwe is a must read and so is Celik's on p wave dispersion associated with obstructive pulmonary disease. ${ }^{18}$ Papers on sickle cell anemia ${ }^{19}$, IgA nephropathy ${ }^{20}$, and pseudobulbar palsy ${ }^{21}$, spice this series.

Olusegun-Joseph et. al have written on mortality in an emergency department in Nigeria ${ }^{22}$, while Sarwar's paper $^{23}$ on MAO-A gene association with aggression in Pakistan concludes this NCD section.

\section{Infections}

Now to infections. Yes, you guessed right! We have failed to resist the temptation and included papers on Covid-19: roles of exercise and immunity ${ }^{24}$, and mortality among Indian patients; ${ }^{25}$ and a paper on Corona-Virus reaching far beyond the common cold. ${ }^{26}$ So we are deep in the infectious disease territory: risk factors for multiple drug resistant bacteria in urinary tract infections $(\mathrm{UTI})^{27}$, and UTI in nurses and civil servants. ${ }^{28}$

We have several papers on TB: hearing-threshold in drug-resistant $\mathrm{TB}^{29}$; non adherence to MDR-TB treatment in Uganda ${ }^{30}$, and TB/HIV service integration in Kampala. ${ }^{31} \mathrm{HPV} / \mathrm{HIV}$ confection in Kenya ${ }^{32}$, and first line HIV treatment failure in Ethiopia ${ }^{33}$, conclude the HIV papers. We have a series of papers on malaria ${ }^{34}$, septic shock ${ }^{35}$, and wound infection with $\mathrm{MRSA}^{36}$ concluding the infections disease section.

\section{Reproductive and child health}

Now to reproductive and child health. There are papers on ectopic pregnancy in the Gambia ${ }^{37}$, postpartum haemorrhage management in Kenya ${ }^{38}$ and South Afri$\mathrm{ca}^{39}$ and Caesarean section deliveries in Ibadan in Nigeria. ${ }^{40}$ We also have papers on married women procuring abortions ${ }^{41}$, fetal ear length ${ }^{42}$, infertility ${ }^{43}$, and paternity in motherless children. ${ }^{44}$ These are followed by papers on birth length ${ }^{45}$, neonatal asphyxia ${ }^{46}$, and neonatal mortality ${ }^{47}$, and factors associated with underweight in Ethiopia. ${ }^{48}$

Then we have a cocktail of papers on anti-inflammatory potential of Eucalyptus ${ }^{49}$, herbal medicine use in Ethiopia $^{50}$, and traditional bone-setting in Tanzania ${ }^{51}$.

This ushers in surgical issues: intestinal stoma in Ugan$\mathrm{da}^{52}$, phthisis bulbi in Nigeria ${ }^{53}$, cataract surgery in Ghana ${ }^{54}$, mercury in dentstry ${ }^{55}$, dental health insurance hygiene ${ }^{56}$, and ethical issues in seeking consent for health procedures in the Democratic Republic of the Congo. ${ }^{57}$ We hope that you will enjoy this hybrid issue of AHS. Good reading.

\section{References}

1. Ma J, Zhao Y-H, Fan H, Liu J. The efficacy of dapagliflozin for type 1 diabetes: a meta-analysis of randomized controlled studies. Afri Health Sci. 2021;21(1):1 7. https://dx.doi.org/10.4314/ahs.v21i1.2

2. Sattar NA, Shaheen S, Hussain F, Jamil A. Association analysis of vitamin $\mathrm{D}$ receptor gene polymorphisms in North England population with Type 2 diabetes mel- 
litus. Afri Health Sci. 2021;21(1):8-14. https://dx.doi. org/10.4314/ahs.v21i1.3

3. Hameed T, Khan Z, Imran M, Ali S, Albegali AA, Ullah MI, et al. Associations of transcription factor 7-Like 2 (TCF7L2) gene polymorphism in patients of type 2 diabetes mellitus from Khyber Pakhtunkhwa population of Pakistan. Afri Health Sci. 2021;21(1):1522. https://dx.doi.org/10.4314/ahs.v21i1.4

4. Chetoui A, Kaoutar K, Boutahar K, El Kardoudi A, Elmoussaoui S, Chigr F, et al. Prevalence of overweight/obesity and its associated factors among a sample of Moroccan type 2 diabetes patients. Afri Health Sci. 2021;21(1):23-31. https://dx.doi.org/10.4314/ahs. v21i1.5

5. Adam HMI, Elmosaad YM, Ahmed AEE, Khan A , Mahmud I. Dietary knowledge, attitude and practice among type 2 diabetes mellitus patients in Sudan: a hospital-based cross-sectional study. Afri Health Sci. 2021;21(1):32-40.https://dx.doi.org/10.4314/ahs. v21i1.6

6. Latifa M, Fatima DD, Farida M, Rachid S. Intra-tumoral distribution of Ki-67 and Cyclin D1 in ER+ mammary carcinoma: quantitative evaluation. Afri Health Sci. 2021;21(1):41-6. https://dx.doi.org/10.4314/ahs. v21i1.7

7. Saberian M, Mehrabani K, Shahraki HR. Clustering time trends of breast cancer incidence in Africa: a 27 -year longitudinal study in 53 countries. Afri Health Sci. 2021;21(1):47-53. https://dx.doi.org/10.4314/ahs. v21i1.8

8. Amin SM, Nwatah VE, Ameh EA, Oyesegun AR, Oyesakin AB. Histopathologic spectrum of childhood tumours in a Tertiary Hospital: a ten-year review. Afri Health Sci. 2021;21(1):54-9. https://dx.doi. org/10.4314/ahs.v21i1.9

9. Rodríguez-Herrera C, López-Jiménez J- d-J, del Toro-Valero A, Torres-Carrillo NM, Torres-Carrillo $\mathrm{N}$, Godínez-Peña CA, et al. The Newcastle satisfaction with nursing scales in a Mexican Oncology Hospital. Afri Health Sci. 2021;21(1):60-6. https://dx.doi. org/10.4314/ahs.v21i1.10

10. Okello CD, Mulumba Y, Omoding A, Ddungu H, Welch K, Thompson CL, et al. Characteristics and outcomes of patients with multiple myeloma at the Uganda Cancer Institute. Afri Health Sci. 2021;21(1):67-74. https://dx.doi.org/10.4314/ahs.v21i1.11

11. Opreh OP, Olajubu TO, Akarakiri KJ, Ligenza V, Amos JT, Adeyeye AV, et al. Prevalence and factors associated with hypertension among rural community dwellers in a local government area, South West Nige- ria. Afri Health Sci. 2021;21(1):75-81. https://dx.doi. org/10.4314/ahs.v21i1.12

12. Zong Q, Ma G, Wang T. Uric acid lowering improves insulin sensitivity and lowers blood pressure: a meta-analysis of randomized parallel-controlled clinical trials. Afri Health Sci. 2021;21(1):82-95. https://dx.doi. org/10.4314/ahs.v21i1.13

13. Acar B, Yayla C, Gul M, Karanfil M, Unal S, Uçar F, et al. Monocyte-to-HDL-cholesterol ratio is associated with Ascending Aorta Dilatation in Patients with Bicuspid Aortic Valve. Afri Health Sci 2021;21(1):96-104. https://dx.doi.org/10.4314/ahs.v21i1.14

14. Pepera G, Panagiota Z. Comparison of heart rate response and heart rate recovery after step test among smoker and non-smoker athletes. Afri Health Sci. 2021;21(1):105-11. https://dx.doi.org/10.4314/ahs. v21i1.15

15. Gazibara T, Milic M, Parlic M, Stevanovic J, Mitic N, Maric G, et al. What differs former, light and heavy smokers? Evidence from a post-conflict setting. Afri Health Sci. 2021;21(1):112-22. https://dx.doi. org/10.4314/ahs.v21i1.16

16. Inaç Y, Larivière Y, Hoque M, Van Hal G. Risk factors for hazardous drinking in university students from South Africa and Belgium: a cross-cultural comparison study. Afri Health Sci. 2021;21(1):123-31. https://dx. doi.org/10.4314/ahs.v21i1.17

17. Nyoni-Kachambwa P, Naravage W, James NF, Van der Putten M. A preliminary study of skin bleaching and factors associated with skin bleaching among women living in Zimbabwe. Afri Health Sci. 2021;21(1):132-9. https://dx.doi.org/10.4314/ahs.v21i1.18

18. Celik Y, Yıldırım N, Demir V, Alp C, Sahin O, Doğru MT. Atrial electromechanical delay and $\mathrm{p}$ wave dispersion associated with severity of chronic obstructive pulmonary disease. Afri Health Sci. 2021;21(1):140-9. https://dx.doi.org/10.4314/ahs.v21i1.19

19. Engwa GA, Okolie A, Chidili JPC, Okore PA, Onu PC, Ugwu MO, et al. Relationship of oxidative stress and antioxidant response with vaso-occlusive crisis in sickle cell anaemia. Afri Health Sci. 2021;21(1):150-8. https://dx.doi.org/10.4314/ahs.v21i1.20

20. Khairwa A. Indian scenario of IgA nephropathy: a systematic review and meta-analysis. Afri Health Sci. 2021;21(1):159-65. https://dx.doi.org/10.4314/ahs. v21i1.21

21. Rissardo JP, Caprara AF. Isolated acute pseudobulbar palsy with infarction of artery of percheron: case report and literature review. Afri Health Sci. 2021;21(1):166-71. https://dx.doi.org/10.4314/ahs.v21i1.22 
22. Olusegun-Joseph AD, Akande O, Otrofanowei E, Nwoye EO, Olopade OB, Ajuluchukwu JN. Medical mortality in an emergency department in Nigeria: the transition is obvious! Afri Health Sci. 2021;21(1):172-9. https://dx.doi.org/10.4314/ahs.v21i1.23

23. Sarwar S, Shabana, Hasnain S. Association of variable number of tandem repeats (VNTR) and T941G polymorphism of monoamine oxidase (MAO-A) gene with aggression in Pakistani subjects. Afri Health Sci. 2021;21(1):180-8.https://dx.doi.org/10.4314/ahs. v21i1.24

24. Tokunbo O, Abayomi T, Adekomi D, Oyeyipo I. COVID-19: sitting is the new smoking; the role of exercise in augmenting the immune system among the elderly. Afri Health Sci. 2021;21(1):189-93. https://dx.doi. org/10.4314/ahs.v21i1.25

25. Dhamodharavadhani S, Rathipriya R. COVID-19 mortality rate prediction for India using statistical neural networks and gaussian process regression model. Afri Health Sci. 2021;21(1):194-206. https://dx.doi. org/10.4314/ahs.v21i1.26

26. Coerdt KM, Khachemoune A. Corona viruses: reaching far beyond the common cold. Afri Health Sci. 2021;21(1):207-13.https://dx.doi.org/10.4314/ahs. v21i1.27

27. Guclu E, Halis F, Kose E, Ogutlu A, Karabay O. Risk factors of multidrug-resistant bacteria in community-acquired urinary tract infections. Afri Health Sci. 2021;21(1):214-9. https://dx.doi.org/10.4314/ahs. v21i1.28

28. Kok G, Kocaoz S, Guvenc G, Akyuz A. Prevalence of lower urinary tract symptoms in nurses and civil servants working at a hospital: a cross-sectional study. Afri Health Sci. 2021;21(1):220-9. https://dx.doi. org/10.4314/ahs.v21i1.29

29. Sogebi OA, Adefuye BO, Ajayi EA. Early hearing threshold changes and peculiarities of audiometric assessments among patients in a drug-resistant tuberculosis treatment center. Afri Health Sci. 2021;21(1):230-7. https://dx.doi.org/10.4314/ahs.v21i1.30

30. Batte C, Namusobya MS, Kirabo R, Mukisa J, Adakun S, Katamba A. Prevalence and factors associated with non-adherence to multi-drug resistant tuberculosis (MDR-TB) treatment at Mulago National Referral Hospital, Kampala, Uganda. Afri Health Sci. 2021;21(1):23847. https://dx.doi.org/10.4314/ahs.v21i1.31

31. Katende JN, Omona K. User - provider perspectives to overcome the challenges of TB/HIV service integration at Mulago National Referral Hospital Kampala. Afri Health Sci. 2021;21(1):248-53. https:// dx.doi.org/10.4314/ahs.v21i1.32
32. Karani LW, Musyoki S, Orina R, Khayeka-Wandabwa C, Nyagaka B. Cytological physiognomies and genotype distribution of human papillomaviruses among HPV/HIV co-infected and HPV mono-infected women. Afri Health Sci. 2021;21(1):254-62. https:// dx.doi.org/10.4314/ahs.v21i1.33

33. Genet A, Mekonnen Z, Yizengaw E, Mekonnen D. First line antiretroviral treatment failure and associated factors among people living with HIV in northwest Ethiopia. Afri Health Sci. 2021;21(1):263-72. https://dx.doi.org/10.4314/ahs.v21i1.34

34. Bellazreg F, Slama D, Lasfar NB, Abid M, Zaghouani $\mathrm{H}$, Rouis S, et al. Neurological manifestations following cured malaria: don't forget post-malaria neurological syndrome. Afri Health Sci. 2021;21(1):273-6. https:// dx.doi.org/10.4314/ahs.v21i1.35

35. Kong L, Wu Q, Liu B. The impact of selenium administration on severe sepsis or septic shock: a meta-analysis of randomized controlled trials. Afri Health Sci. 2021;21(1):277-85. https://dx.doi.org/10.4314/ ahs.v21i1.36

36. Thimmappa L, Bhat A, Hande M, Mukhopadhyay C, Devi E, Nayak B, et al. Risk factors for wound infection caused by Methicillin Resistant Staphylococcus aureus among hospitalized patients: a case control study from a tertiary care hospital in India. Afri Health Sci. 2021;21(1):286-94. https://dx.doi.org/10.4314/ahs. v21i1.37

37. Anyanwu M, Titilope G. Ectopic pregnancy at the Gambian Tertiary hospital. Afri Health Sci. 2021;21(1):295-303. https://dx.doi.org/10.4314/ahs. v21i1.38

38. Muthoni DM, Kabue PN, Ambani EK. Factors that influence management of postpartum hemorrhage among midwives in a rural setting in Kenya. Afri Health Sci. 2021;21(1):304-10. https://dx.doi.org/10.4314/ ahs.v21i1.39

39. Ramavhoya TI, Maputle MS, Lebese RT, Makhado L. Midwives' challenges in the management of postpartum haemorrhage at rural PHC facilities of Limpopo province, South Africa: an explorative study. Afri Health Sci. 2021;21(1):311-9. https://dx.doi.org/10.4314/ahs. v21i1.40

40. Ismail WO, Bello IS, Olowookere SA, Ibrahim AO, Agbesanwa TA, Adekunle WA. Caesarean delivery rate and indications at a secondary healthcare facility in Ibadan, South Western Nigeria: a five-year review. Afri Health Sci. 2021;21(1):320-6. https://dx.doi. org/10.4314/ahs.v21i1.41

41. Ojo IE, Ojo TO, Orji EO. Why do married women procure abortion? Experiences from Ile-Ife, south 
western Nigeria. Afri Health Sci. 2021;21(1):327-37. https://dx.doi.org/10.4314/ahs.v21i1.42

42. Idigo F, Ajibo K, Anakwue A-M, Nwogu U, Robinson E. Sonographic measurement of ear length among normal fetuses of pregnant Igbo women in port Harcourt, Nigeria. Afri Health Sci. 2021;21(1):338-48. https://dx.doi.org/10.4314/ahs.v21i1.43

43. Taiwo IA, Adeleye A, Uzoma IC. A possible model for estimating birth length of babies from common parental variables using a sample of families in Lagos, Nigeria. Afri Health Sci. 2021;21(1):349-56. https://dx. doi.org/10.4314/ahs.v21i1.44

44. Sidi-Yakhlef A, Boukhelif M, Metri AA. Socio-demographic determinants of neonatal mortality in Algeria according to MICS4 data (2012-2013). Afri Health Sci. 2021;21(1):357-61. https://dx.doi.org/10.4314/ ahs.v21i1.45

45. Birhan NA, Belay DB. Associated risk factors of underweight among under-five children in Ethiopia using multilevel ordinal logistic regression model. Afri Health Sci. 2021;21(1):362-72. https://dx.doi.org/10.4314/ ahs.v21i1.46

46. Gündüz R, Ağaçayak E, Okutucu G, Karuserci ÖK, Peker N, Çetinçakmak MG, et al. Hysterosalpingography: a potential alternative to laparoscopy in the evaluation of tubal obstruction in infertile patients? Afri Health Sci. 2021;21(1):373-8. https://dx.doi.org/10.4314/ahs. v21i1.47

47. De Kock AA, Kloppers JJF. The impact of motherless paternity testing in a South African population. Afri Health Sci. 2021;21(1):379-84. https://dx.doi. org/10.4314/ahs.v21i1.48

48. Bayih WA, Tezera TG, Alemu AY, Belay DM, Hailemeskel HS, Ayalew MY. Prevalence and determinants of asphyxia neonatorum among live births at Debre Tabor General Hospital, North Central Ethiopia: a cross-sectional study. Afri Health Sci. 2021;21(1):385-96. https://dx.doi.org/10.4314/ahs.v21i1.49

49. Mworia JK, Kibiti CM, Ngeranwa JJN, Ngugi MP. Anti-inflammatory potential of dichloromethane leaf extracts of Eucalyptus globulus (Labill) and Senna didymobotrya (Fresenius) in mice. Afri Health Sci. 2021;21(1):397409. https://dx.doi.org/10.4314/ahs.v21i1.50

50. Zeynu A, Wondimu T, Demissew S. Herbal med- icine used by the community of Koneba district in Afar Regional State, Northeastern Ethiopia. Afri Health Sci. 2021;21(1):410-7.https://dx.doi.org/10.4314/ahs. v21i1.51

51. Card EB, Obayemi JE, Shirima O, Rajaguru P, Massawe $H$, Premkumar A, et al. Patient patronage and perspectives of traditional bone setting at an outpatient orthopaedic clinic in Northern Tanzania. Afri Health Sci. 2021;21(1):418-26. https://dx.doi.org/10.4314/ahs. v21i1.52

52. Ssewanyana Y, Ssekitooleko B, Suuna B, Bua E, Wadeya J, Makumbi TK, et al. Quality of life of adult individuals with intestinal stomas in Uganda: a cross sectional study. Afri Health Sci. 2021;21(1):427-36. https:/ / dx.doi.org/10.4314/ahs.v21i1.53

53. Adewara BA, Badmus SA, Olugbade OT, Ezeanosike E, Adegbehingbe BO. Distribution of phthisis bulbi and status of fellow eyes at a tertiary eye-care centre in Nigeria: a ten-year review. Afri Health Sci. 2021;21(1):437-44.https://dx.doi.org/10.4314/ahs. v21i1.54

54. Kyei S, Amponsah BK, Asiedu K, Akoto YO. Visual function, spectacle independence, and patients' satisfaction after cataract surgery- a study in the Central Region of Ghana. Afri Health Sci. 2021;21(1):445-56. https:/ / dx.doi.org/10.4314/ahs.v21i1.55

55. Makanjuola JO, Ekowmenhenhen UI, Enone LL, Umesi DC, Ogundana OM, Arotiba GT. Mercury hygiene and biomedical waste management practices among dental health-care personnel in public hospitals in Lagos State, Nigeria. Afri Health Sci. 2021;21(1):45769. https://dx.doi.org/10.4314/ahs.v21i1.56

56. Idon PI, Sotunde OA, Ogundare TO, Yusuf J, Makanjuola JO, Mohammed A, et al. Access to root canal treatment in a Nigerian sub-population: assessment of the effect of dental health insurance. Afri Health Sci. 2021;21(1):470-7. https://dx.doi.org/10.4314/ahs. v21i1.57

57. Nzaumvila D, Ntotolo P, Govender I, lukanu P, Niati JDL, Sanduku D, et al. Knowledge and practices of seeking informed consent for medical examinations and procedures by health workers in the Democratic Republic of Congo. Afri Health Sci. 2021;21(1):478-88. https://dx.doi.org/10.4314/ahs.v21i1.58 